\title{
The Effect of Different Concentrations of Nitrogen and Phosphorous on the Production of Lipid Metabolites in Haematococcus Pluvialis UTEX 25051
}

\section{Brenda Seleny Hoyos Gutierrez ( $\boldsymbol{\sigma}$ bhoyosg@eafit.edu.co )}

Department of Biological Sciences, EAFIT University, Carrera 49, número 7 sur 50, Cra. 49, Medellín, Colombia, 050001 https://orcid.org/0000-0001-7363-5902

\section{Alejandra Miranda}

Department of Biological Sciences, EAFIT University, Carrera 49, número 7 sur 50, Cra. 49, Medellín, Colombia, 050001

\section{Diana Meneses}

Department of Biological Sciences, EAFIT University, Carrera 49, número 7 sur 50, Cra. 49, Medellín, Colombia, 050001

\section{Gabriel Vargas}

I\&D Cementos Argos S.A, Argos Center for Innovation (CAPI), Carrera 49, número 7 sur 50, Cra. 49, Medellín, Colombia, 050001

\section{Alex Sáez}

Department of Biological Sciences, EAFIT University, Carrera 49, número 7 sur 50, Cra. 49, Medellín, Colombia, 050001

\section{Research}

Keywords: Astaxanthin, Haematococcus pluvialis, lipids, antioxidants, cell morphology.

Posted Date: March 4th, 2021

DOl: https://doi.org/10.21203/rs.3.rs-262577/v1

License: (c) (i) This work is licensed under a Creative Commons Attribution 4.0 International License. Read Full License 

ON THE PRODUCTION OF LIPID METABOLITES IN Haematococcus pluvialis UTEX $2505^{1}$

Brenda Hoyos $^{\mathrm{a}}{ }^{2}$, Alejandra Miranda ${ }^{\mathrm{b}}$, Diana Meneses $^{\mathrm{c}}$, Gabriel Vargas $^{\mathrm{d}}$ and Alex Sáez

${ }^{1}$ Date of submission: 20 of February of 2021

${ }^{a}$ Department of Biological Sciences, EAFIT University, Carrera 49, número 7 sur 50, Cra. 49, Medellín, Colombia, 050001

${ }^{b}$ Department of Process engineering, EAFIT University, Carrera 49, número 7 sur 50, Cra. 49, Medellín, Colombia, 050001

${ }^{c}$ Department of Process engineering, EAFIT University, Carrera 49, número 7 sur 50, Cra. 49, Medellín, Colombia, 050001

${ }^{d}$ I\&D Cementos Argos S.A, Argos Center for Innovation (CAPI), Carrera 49, número 7 sur 50, Cra. 49, Medellín, Colombia, 050001

${ }^{d}$ Department of Process engineering, EAFIT University, Carrera 49, número 7 sur 50, Cra. 49, Medellín, Colombia, 050001

${ }^{2}$ Corresponding author: bhoyosg@eafit.edu.co, +57300 5252383

\section{ABSTRACT}

Microalgae as Haematococcus pluvialis produce lipid metabolites of great interest for different industries as the nutraceutical, pharmaceutical, cosmetic, among other. Currently, one of the main limitations for the massive commercialization of these metabolites are the low yields between cell growth and the production of lipid metabolites. Thus, a better understanding of culture parameters that allow to get a balance between both variables is needed. Herein we evaluated the effect of Bold's Basal Medium (BBM) on the production of lipid metabolites of high biotechnological value in Haematococcus pluvialis UTEX 2505. A factorial experimental design of $3^{2}$ was used whereby the concentrations of the nitrogen and phosphorus source $(0.2,0.6$ and $1.0 \mathrm{~g} / 1)$ in the BBM culture medium were varied. Cell growth was measured, showed the highest concentration $(1.148 \pm 0.842$ $\mathrm{g} / \mathrm{l}$ ) for the treatment with the highest nitrate and phosphate content (a concentration of $1.0 \mathrm{~g} / \mathrm{l}$ for both). The Astaxanthin content showed a maximum value of $76.22 \pm 3.02 \square \mathrm{g} / \mathrm{mL}$ for treatment with low nitrate $(0.2 \mathrm{~g} / \mathrm{L})$ and medium phosphate $(0.6 \mathrm{~g} / \mathrm{L})$. The antioxidant capacity was determined by the ORAC method, achieving superior values to those found in the literature for compounds such as vitamins $\mathrm{E}$ and $\mathrm{C}$. The results suggested that low concentrations of nutrients, nitrate and phosphate have a positive effect on the concentration of lipid metabolites and affirm that the biomass of $H$. pluvialis UTEX 2505 is an excellent source of antioxidants and rich in essential fatty acids for human nutrition.

Key words: Astaxanthin, Haematococcus pluvialis, lipids, antioxidants, cell morphology. 
THE EFFECT OF DIFFERENT CONCENTRATIONS OF NITROGEN AND PHOSPHOROUS

ON THE PRODUCTION OF LIPID METABOLITES IN Haematococcus pluvialis UTEX 2505

INTRODUCTION

Haematococcus pluvialis is a unicellular freshwater microalga that can synthesize a red pigment and potent antioxidant known as astaxanthin. In addition, when the conditions for cell growth are favorable, $H$. pluvialis grows as a green cell with two flagella (vegetative stage) that provide mobility. On the other hand, in extreme environmental conditions (i.e., nutrient limitation), the microalga undergoes physiological and morphological changes that lead to the loss of its flagella and the development of red cysts spanning the center of the cell (palmella stage) to its periphery, ultimately reaching the cytoplasm (aplanospore) stage, when there is an increase in lipid biosynthesis and carotenogenesis that allows $H$. pluvialis to survive in a dormant state (Saha et al., 2013). During the aplanospore stage, when the maximum encystment is expected, H. pluvialis can produce $1-4 \%$ of the dry weight astaxanthin, from which approximately $95 \%$ of the carotenoid is esterified (5\% is free astaxanthin, $25 \%$ di-ester and $70 \%$ monoester) with fatty acids. These are stored in cytosolic lipid bodies rich in triacyl-triglycerides (Camacho et al., 2013; Chen et al., 2015); recent studies (Shang et al., 2016) note the existence of biochemical evidence that confirms that astaxanthin and cellular fatty acids have a linear correlation when $H$. pluvialis faces extreme conditions. For example, Chen et al. (2015) presents a possible mechanism of coordination for the synthesis of astaxanthin and fatty acids from $H$. pluvialis. However, this process needs to be further investigated for a broader understanding. Nevertheless, lipid metabolites such as astaxanthin have a worldwide market in many industries, such as food, cosmetics, etc. Due to their variety of applications (Orosa et al., 2005) and the benefits they provide to humans (e.g., protection against numerous forms of cancer and UV rays, use in food supplements, amongst others) (Wang et al., 2016; Satoh et al., 2016), interest in efficiently obtaining them has increased in recent years.

Thus, the main biotechnological challenges for the bulk production of lipid metabolites from $H$. pluvialis are how to enhance the cell growth rate, as well as the synthesis and extraction yield of metabolites.

The latter two challenges have been explored in various ways to improve them by means of stress induction in microalgae. For instance, (Orosa et al., 2005) found that different concentrations of $\mathrm{NaNO}_{3}$ had a significant effect on cell growth and astaxanthin accumulation. Similarly, Choi et al. (2011) studied the impact of differing light intensities on $H$. pluvialis and determined that this can also affect astaxanthin concentration. Therefore, the present study aims to investigate the effect of low concentrations of nitrogen and phosphorus source on the morphology of H. pluvialis UTEX 2505, as well as other important parameters like specific growth rate, lipid content, the amount of astaxanthin and the antioxidant capacity, which will deepen the understanding of the incidence of the culture media to produce lipid metabolites in the microalgae. 
The strain Haematococcus pluvialis UTEX 2505 was obtained from the Culture Collection of Algae at the University of Texas at Austin (UTEX) and the corresponding experimentation was carried out at the Laboratory of Biotechnology of the Argos Center for Innovation at EAFIT University in Medellín, Colombia.

Initially, the cryogenized strain was thawed at $35^{\circ} \mathrm{C}$ in a serological water bath (Memmert, WNB 7-45 Germany). Then, it was pre-inoculated in a solid culture Bold's Basal Medium (BBM), composed of (g/l): $25.0 \mathrm{NaNO}_{3} ; 2.5 \mathrm{CaCl}_{2} 2 \mathrm{H}_{2} \mathrm{O} ; 7.5 \mathrm{MgSO}_{4} \cdot 7 \mathrm{H}_{2} \mathrm{O} ; 7.5 \mathrm{~K}_{2} \mathrm{HPO}_{4} ; 17.5 \mathrm{KH}_{2} \mathrm{PO}_{4}$; $2.5 \mathrm{NaCl} ; 10.0$ EDTA Na2; $4.9 \mathrm{FeSO}_{4} ; 11.5 \mathrm{H}_{3} \mathrm{BO}_{4} ; 8.8 \mathrm{ZnSO}_{4} ; 1.4 \mathrm{MnCl}_{2} \cdot 4 \mathrm{H}_{2} \mathrm{O} ; 0.7 \mathrm{MoO}_{3} ; 1.5$ $\mathrm{CuSO}_{4} \cdot 5 \mathrm{H}_{2} \mathrm{O} ; 0.5\left(\mathrm{NO}_{3}\right)_{2} \mathrm{Co} 6 \mathrm{H}_{2} \mathrm{O}$ (Cifuentes et al., 2003).

Subsequently, the biomass from the Petri dishes was inoculated in $40 \mathrm{ml}$ of culture medium contained in a $50 \mathrm{ml}$ Erlenmeyer flask and used as a pre-inoculum. Once sufficient biomass was obtained, $860 \mathrm{ml}$ of sterile BBM culture medium was inoculated with $100 \mathrm{ml}$ of algal suspension. The growing conditions were $1000 \mathrm{ml}$ of work volume at a temperature $27^{\circ} \mathrm{C} \pm 3$, artificial light (LED) with an intensity of $55 \pm 4 \mu \mathrm{mol} / \mathrm{m}^{2}$ s, enriched air with $\mathrm{CO}_{2}$ at $3 \%$ and a $\mathrm{pH}$ of between 6.4 and 6.6.

\section{Morphological evaluation}

Microscopy

94

95

The structure of the cells of $H$. pluvialis UTEX 2505 was observed in an optical microscope Zeiss, Axio Scope A1 incorporating an Axiocam ICc 5 digital camera. Moreover, a Phenom G2 ProDesktop scanning electron microscope (SEM) was used to study the variation in cell surface morphology. For that purpose, the cells were concentrated by centrifugation at $4000 \mathrm{rpm}$ for 10 minutes. The samples were fixed with $2.5 \%$ glutaraldehyde in 0.1 Molar of Cocodilatos Buffer at $\mathrm{pH} 7.4$, then washed three times with a solution of PSB at $0.1 \mathrm{M}$. Subsequently, the samples were gradually dehydrated with 20,40,60, 70 and $100 \%$ of ethanol. Finally, using supercritical fluids, they were dried using a Samdri - PVT - 3D, Tousimis. Furthermore, for the photographic shots in the SEM, a Gold-Palladium coating was made using an SC7620 Mini Sputter Coater (Gao et al., 2012). The morphological evaluation of $H$. pluvialis UTEX 2505 was performed in two separated groups: a) based on different stages of growth; and b) based on the effect of the different concentrations of phosphate and nitrate on the last stage of growth (aplanospore).

\section{Biomass quantification}

The biomass of $H$. pluvialis UTEX 2505 was quantified by dry weight, with the samples taken every 24 hours until the stationary phase was reached (Castillo et el., 2017). A three-branch manifold filtration vacuum was used, with sterile cellulose ester filters (Advantec MFS, Inc) with a diameter of $47 \mathrm{~mm}$, pore size of $0.45 \mu \mathrm{m}$ and moisture scales of Sartorius Mark 3.

\section{Kinetic modeling}


The kinetic parameters of the growth of $H$. pluvialis UTEX 2505 were evaluated with the logistic model, using the following equation:

$$
X=\left(X_{\max } X_{0} e^{\mu t}\right) /\left(X_{\max }+X_{0}\left(e^{\mu t}-1\right)\right)
$$

where $X$ is the biomass, $X_{\max }$ the maximum biomass obtained, $\mu$ the specific growth rate and the cultivation time in days.

\section{Quantification of astaxanthin}

A visible ultraviolet spectrophotometer Halo RB-10 was used to quantify astaxanthin with a wavelength of $472 \mathrm{~nm}$ and an extraction methodology suggested by Zhang et al. (2009). Then, 10 $\mathrm{ml}$ of $100 \%$ dimethilsulfoxide (DMSO) were added to the concentrated biomass, and this solution placed in an ultrasound VWR at $4{ }^{\circ} \mathrm{C}$ for 60 minutes. After 16 hours, the solution was transferred to a serological bath for 40 minutes at $85{ }^{\circ} \mathrm{C}$. The equation used for the quantification of the astaxanthin was:

$\left.\operatorname{Astaxanthin}(\mu \mathrm{g} / \mathrm{ml})=\left(A_{492} * 10^{6} * V\right) /\left(E_{1 \mathrm{~cm}}^{1 \%}\right) * 100\right)$

where $A_{492}$ is the absorbance calculated at $492 \mathrm{~nm}, 10^{6}$ the factor for expressing carotenoids, V the volume of the solvent used in $\mathrm{ml}, E_{1 \mathrm{~cm}}^{1 \%}$ the specific extraction coefficient for astaxanthin in $\mu \mathrm{g} / \mathrm{ml}$, with a coefficient to cancel the percentage of 100 .

\section{Determination of total lipids}

The extraction of the lipids was performed by immersion or simple reflux in Soxhlet (Luque de Castro et al., 2010), using petroleum ether as the drag solvent at a boiling temperature of $57{ }^{\circ} \mathrm{C}$. The extract with the lipid content (oil extract) was concentrated to reduced pressure, after which the methyl esters of the fatty acids were obtained through extraction from H. pluvialis UTEX 2505 by means of direct transesterification, as was suggested by (Dai et al., 2014) using 7\% of KOH of the weight of the oil extract. Next, it was mixed with methanol at a molar ratio of 1:6 for $20 \mathrm{~min}$ at $400 \mathrm{rpm}$ and $60{ }^{\circ} \mathrm{C}$. 
THE EFFECT OF DIFFERENT CONCENTRATIONS OF NITROGEN AND PHOSPHOROUS

ON THE PRODUCTION OF LIPID METABOLITES IN Haematococcus pluvialis UTEX 2505

146 Table 1. Treatments of the factorial experimental design $3^{2}$ for the study of the culture medium of 147 H. pluvialis UTEX 2505.

\begin{tabular}{ccccccc}
\hline Levels & Nomenclature & Nitrate & Phosphate & Nitrate $(\mathrm{g} / \mathrm{l})$ & $\begin{array}{c}\text { Phosphate } \\
(\mathrm{g} / \mathrm{l})\end{array}$ \\
\hline 1 & 1 & $\mathrm{NaPa}$ & High & High & 1.0 & 1.0 \\
0 & 0 & $\mathrm{NmPm}$ & Medium & Medium & 0.6 & 0.6 \\
-1 & -1 & $\mathrm{NbPb}$ & Low & Low & 0.2 & 0.2 \\
1 & 0 & $\mathrm{NaPm}$ & High & Medium & 1.0 & 0.6 \\
1 & -1 & $\mathrm{NaPb}$ & High & Low & 1.0 & 0.2 \\
0 & 1 & $\mathrm{NmPa}$ & Medium & High & 0.6 & 1.0 \\
0 & -1 & $\mathrm{NmPb}$ & Medium & Low & 0.6 & 0.2 \\
-1 & 1 & $\mathrm{NbPa}$ & Low & High & 0.2 & 1.0 \\
-1 & 0 & $\mathrm{NbPm}$ & Low & Medium & 0.2 & 0.6 \\
\hline
\end{tabular}

148

149

150

151

152

153

154

155

156

157

158

159

160

161

162

163

164

165

166

167
The mixture was kept at room temperature for $18 \mathrm{~h}$ to separate the phase containing the esters from the glycerin. Finally, a gas chromatograph Shimadzu, GC 2014, was used. The volume of the sample injected was $1 \mu 1$, with injection mode Split and a Column RT-2560 with a film thickness of $0.20 \mu \mathrm{m}$, column length of $100 \mathrm{~m}$ and an internal diameter of $0.25 \mathrm{~mm}$.

\section{Determination of antioxidant capacity}

The determination of the antioxidant capacity was carried out by the Fluorometric method known as the Oxygen Radical Absorbance Capacity (ORAC) assay (Zapata et al., 2014) using TROLOX® as the standard solution. The runs were performed at a length of excitation and emission of $493 \mathrm{~nm}$ and $515 \mathrm{~nm}$, respectively, according to the following equation:

$O R A C=\left(\left(A U C-A U C^{\circ}\right) /\left(A U C_{T R O L O X}-A U C\right)\right) f(T R O L O X)$. The ORAC antioxidant capacity was expressed in micromoles of Trolox per $100 \mathrm{~g}$ of sample. Whereas AUC is the area under the curve for the sample, $\mathrm{AUC}^{\circ}$ is the area under the curve for control, while AUC TROLOX® is the area under the curve for TROLOX® and $\mathrm{f}$ the dilution factor of the extracts (Rautenbach et al., 2010; Naranjo et al., 2011).

\section{Statistical experimental design}

To study the effect of the variation of the concentration of nutrients on the production of lipid metabolites of $H$. pluvialis UTEX 2505, a factorial experimental design $3^{2}$ was used, where 
macronutrients such as phosphates and nitrates were the factors and the decrease in concentration (with respect to the BBM) corresponds to the levels of $0.2,0.6$ and $1.0 \mathrm{~g} / \mathrm{l}$. The treatments were carried out in triplicate, and therefore there were a total of 27 experimental units.

The response variables were the cell growth, accumulation of astaxanthin and total lipids, to which an analysis of variance (ANOVA) was applied with a confidence level of $95 \%$. The statistical analysis of the results was carried out using version XVI of the Statgraphics Centurión software.

\section{RESULTS}

\section{Morphological evaluation}

Figure 1.A corresponds to the morphological changes of $H$. pluvialis UTEX 2505 during its growth. Also, in Figure 1.B there was a transition from the green color (vegetative stage) to orange/brown (palmella stage) with the formation of small red cysts inside the cell and a gradual increase in cell diameter from 10 up to $40 \mu \mathrm{m}$. Subsequently, from the palmella to aplanospore stage, the synthesis of astaxanthin increased and the culture went from being brown to red, along with the cells reaching up to $60 \mu \mathrm{m}$ in diameter. Meanwhile, Figure 1.C indicates the fact that there was a formation of roughness on the surface of the cell in the aplanospore stage, unlike the smooth surface of the vegetative stage. Regarding the effect of the factors on the aplanospore growth stage, no changes were observed on the surface of the $H$. pluvialis UTEX 2505 cell (Figure 2).

\section{Effect of low concentrations of nitrate and phosphate on cell growth}

The effect of reducing the concentrations of nutrients like the phosphates and nitrates was negative with respect to the cell growth variable. The $\mathrm{NaPa}$ treatment showed greater cellular growth, of $1.14 \mathrm{~g} / \mathrm{l}$, while the treatments with low nitrates $\mathrm{NbPm}$ and $\mathrm{NbPb}$ showed the lowest cellular concentrations, 0.54 and $0.58 \mathrm{~g} / 1$, respectively (Figure 3).

The cell growth $(\mu)$ of the treatments ranged from 0.13 to 0.36 days $^{-1}$, as shown in Table 1 , while correspondingly the values of $\mathrm{R}^{2}$ ranged from 0.84 to 0,99 , which indicates a strong linear relationship amongst the regression variables. With the ANOVA, it was determined that there are no significant differences between the treatments with respect to $\mu$. 


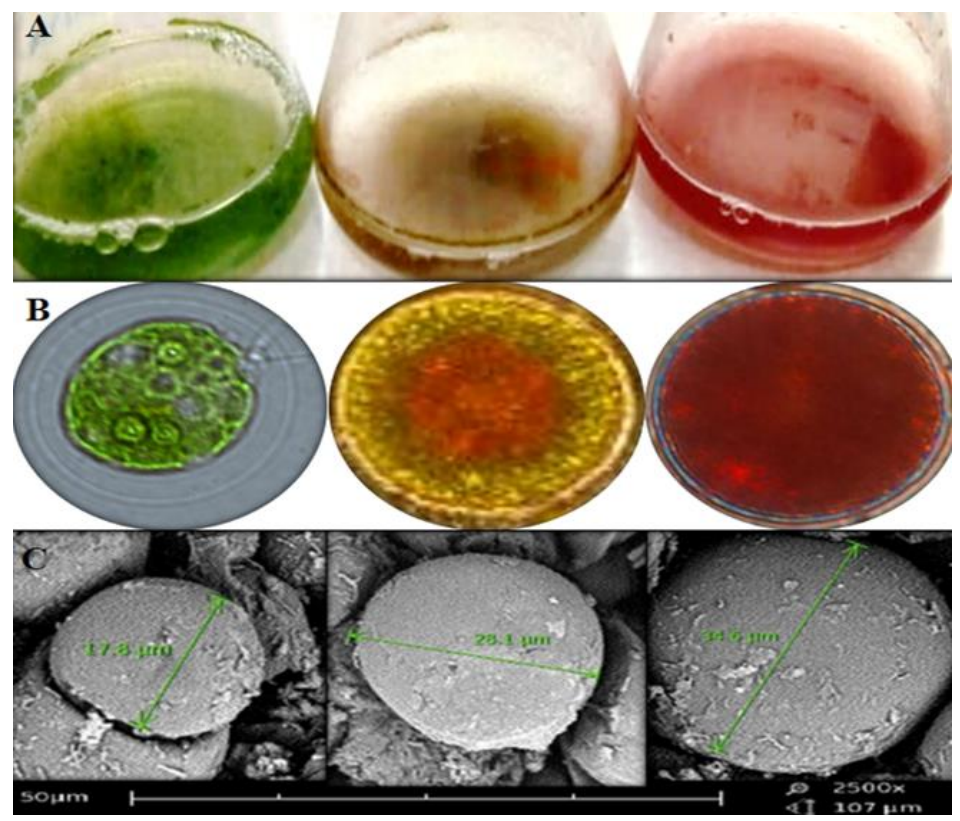

Figure 1. Micrographs of $H$. pluvialis UTEX 2505 in its main three growth stages: A. Microalga
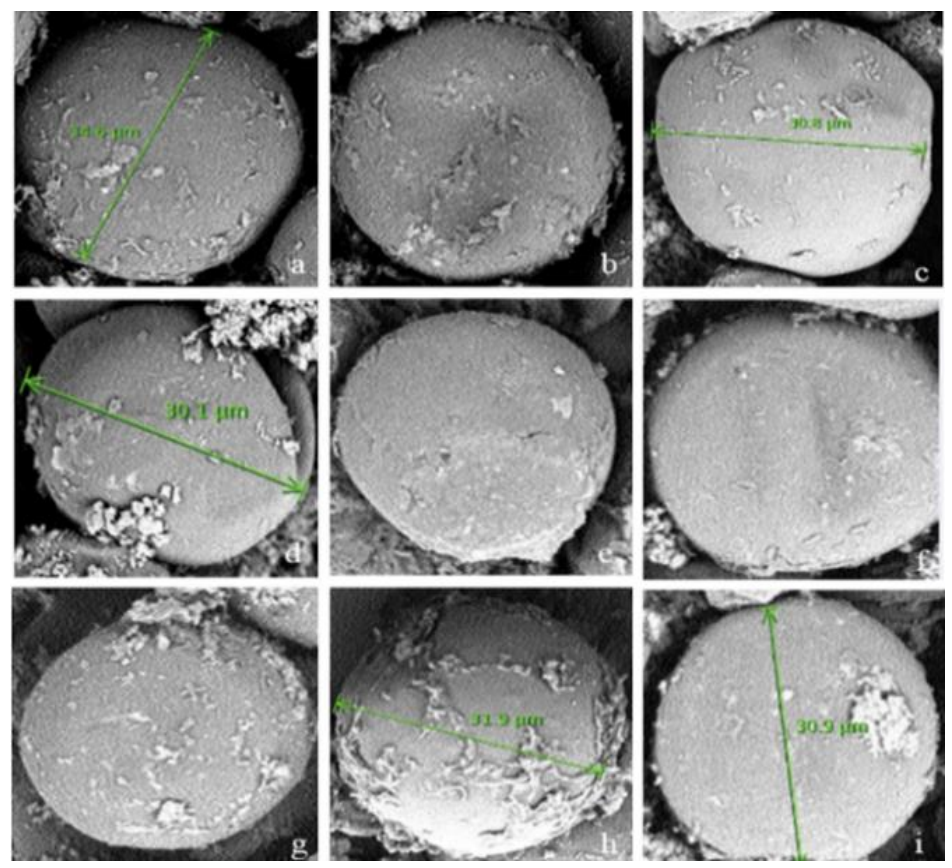

203 Figure 2. Morphology of the cell surface in the last stage of cell growth (aplanospora), taken with 
THE EFFECT OF DIFFERENT CONCENTRATIONS OF NITROGEN AND PHOSPHOROUS

ON THE PRODUCTION OF LIPID METABOLITES IN Haematococcus pluvialis UTEX 2505

206 The ANOVA presented a significant difference amongst the treatments for the response variable of productivity, where $\mathrm{NaPa}$ reached values of up to $0.05 \mathrm{~g} / \mathrm{l}$ day.

\section{Extraction of astaxanthin}

227

Figure 4 displays the results obtained for the effect of the factors on the production of the astaxanthin of $H$. pluvialis UTEX 2505 and it was found with the ANOVA that there are statistically significant differences amongst the treatments, with a P-value of 0.000 . The treatment $\mathrm{N}_{\mathrm{b}} \mathrm{P}_{\mathrm{m}}$ showed greater accumulation of the astaxanthin, with $76.22 \mu \mathrm{g} / \mathrm{ml}$, while the lowest accumulation of the carotenoid was $39,27 \mu \mathrm{g} / \mathrm{ml}$ on average with the treatment $\mathrm{N}_{\mathrm{a}} \mathrm{P}_{\mathrm{a}}$.

The equation that best describes the behavior of astaxanthin with respect to the factors is shown below, with an adjusted $R^{2}$ of $73.6 \%$.

$$
\begin{aligned}
\text { Astaxanthin } & =32.4163-20.9699 * \text { Nitrate }-7.07806 * \text { Phosphate }+9.83783 \\
& * \text { Nitrate }^{2}-12.1868 * \text { Nitrate } * \text { Phosphate }+0.4385 * \text { Phosphate }
\end{aligned}
$$

\section{Lipid extraction}

The results for the total lipids, saturated and unsaturated fatty acids, are shown in Figure 5. The highest lipid accumulation was of $6.1 \mathrm{~g} / 100 \mathrm{~g}$ and was obtained with $\mathrm{NmPb}$, while in contrast the lowest accumulation was $3.46 \mathrm{~g} / 100 \mathrm{~g}$ with $\mathrm{NbPb}$. The ANOVA showed significant differences amongst the treatments, with a P-value of 0.0023 .

Table 2. Kinetic parameters obtained from the logistic model with H. pluvialis UTEX 2505.

\begin{tabular}{lllll}
\hline Treatment & $\mu\left(\right.$ day $\left.^{-1}\right)$ & Xmax $(\mathrm{g} / \mathrm{l})$ & Productivity $(\mathrm{g} / \mathrm{l}$ days $)$ & $\mathrm{R}^{2}$ \\
\hline $\mathrm{NaPa}$ & $0.15 \pm 0.085$ & $1.15 \pm 0.057$ & $0.053 \pm 0.002$ & 0.89 \\
$\mathrm{NaPm}$ & $0.18 \pm 0.023$ & $1.02 \pm 0.051$ & $0.046 \pm 0.002$ & 0.88 \\
$\mathrm{NaPb}$ & $0.14 \pm 0.048$ & $0.90 \pm 0.045$ & $0.044 \pm 0.002$ & 0.99 \\
$\mathrm{NmPa}$ & $0.36 \pm 0.503$ & $0.77 \pm 0.038$ & $0.035 \pm 0.001$ & 0.91 \\
$\mathrm{NmPm}$ & $0.24 \pm 0.413$ & $0.77 \pm 0.038$ & $0.032 \pm 0.001$ & 0.95 \\
$\mathrm{NmPb}$ & $0.29 \pm 0.223$ & $0.71 \pm 0.036$ & $0.043 \pm 0.002$ & 0.95 \\
$\mathrm{NbPa}$ & $0.29 \pm 0.212$ & $0.69 \pm 0.034$ & $0.031 \pm 0.001$ & 0.93 \\
$\mathrm{NbPm}$ & $0.26 \pm 0.826$ & $0.54 \pm 0.027$ & $0.022 \pm 0.001$ & 0.84 \\
\hline
\end{tabular}


THE EFFECT OF DIFFERENT CONCENTRATIONS OF NITROGEN AND PHOSPHOROUS

ON THE PRODUCTION OF LIPID METABOLITES IN Haematococcus pluvialis UTEX 2505

$\begin{array}{lllll}\mathrm{NbPb} & 0.23 \pm 0.346 & 0.58 \pm 0.029 & 0.024 \pm 0.002 & 0.96\end{array}$
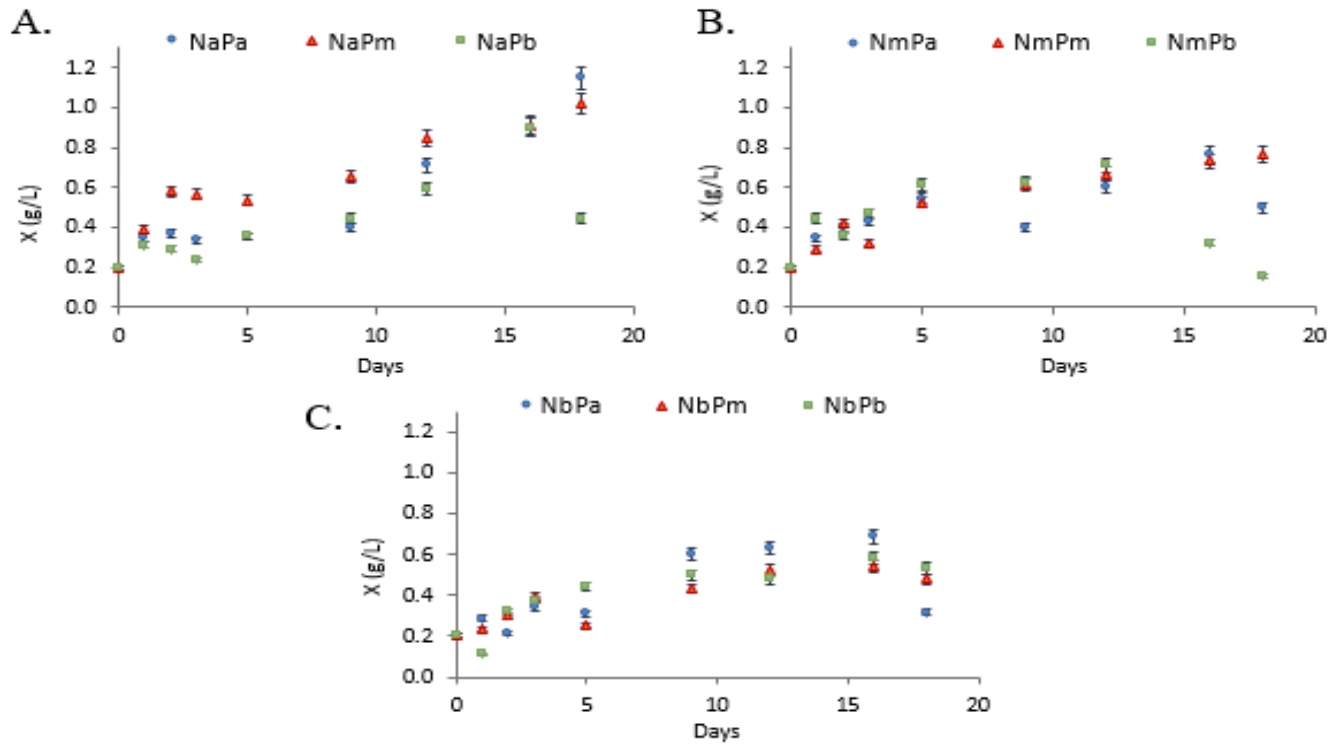

Figure 3. Growth kinetics for the treatments, where $\mathrm{X}$ is the biomass in $\mathrm{g} / \mathrm{l}$ in a time range of 18 days.

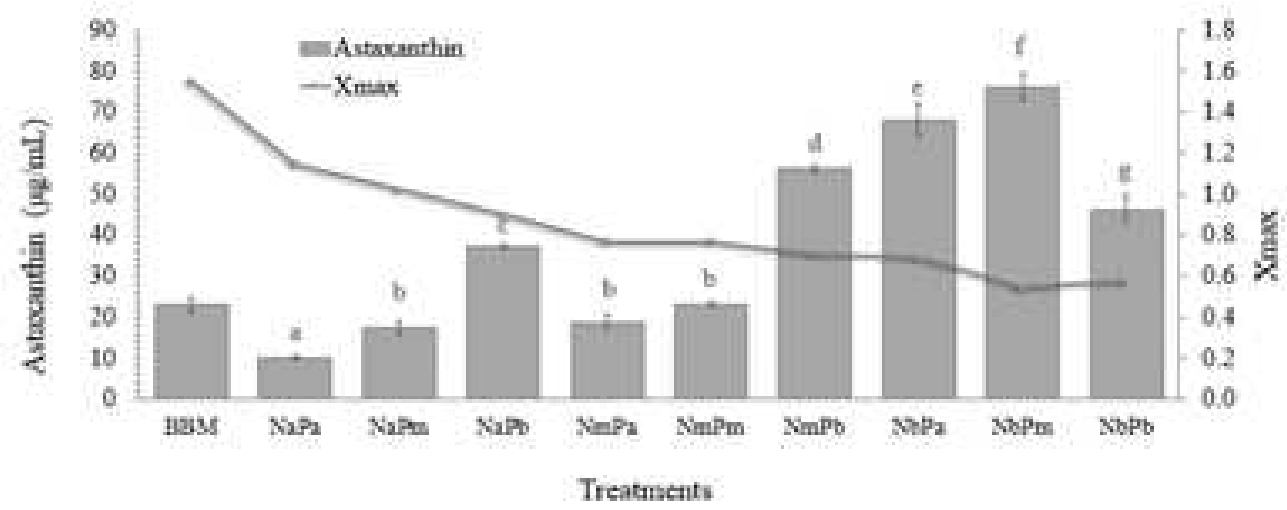

Figure 4. Relationship between the concentration of astaxanthin in $\mu \mathrm{g} / \mathrm{ml}$ of $H$. pluvialis UTEX 2505 and the maximum biomass for all the treatments. Equal letters correspond to statistically homogeneous groups according to Fisher's minimum significant difference test (LSD), with a 
A

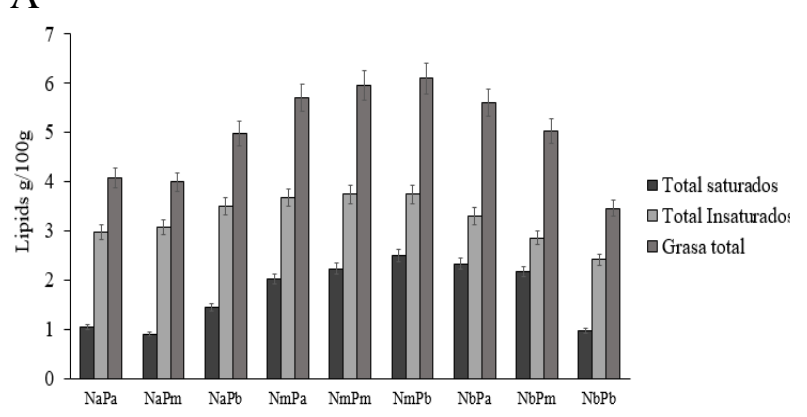

B

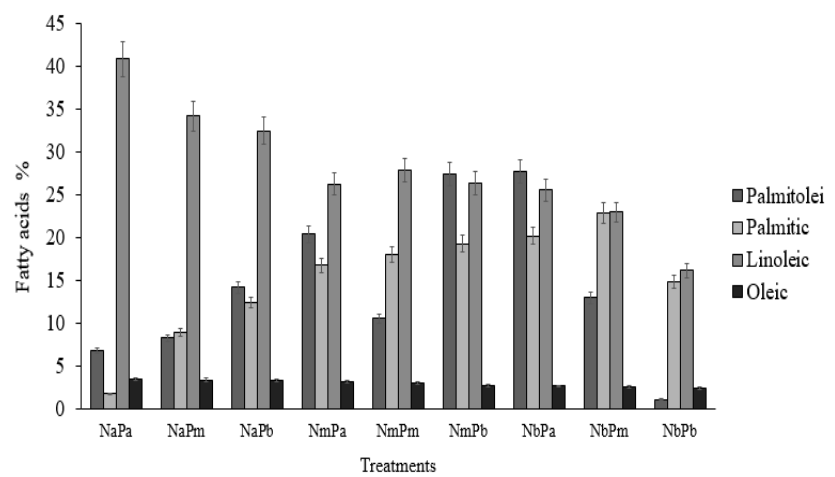

243

Figure 5. A. Lipid concentration (g/100g of biomass) of H. pluvialis UTEX 2505 for the different treatments. B. Percentage of the main fatty acids synthetized with each treatment.

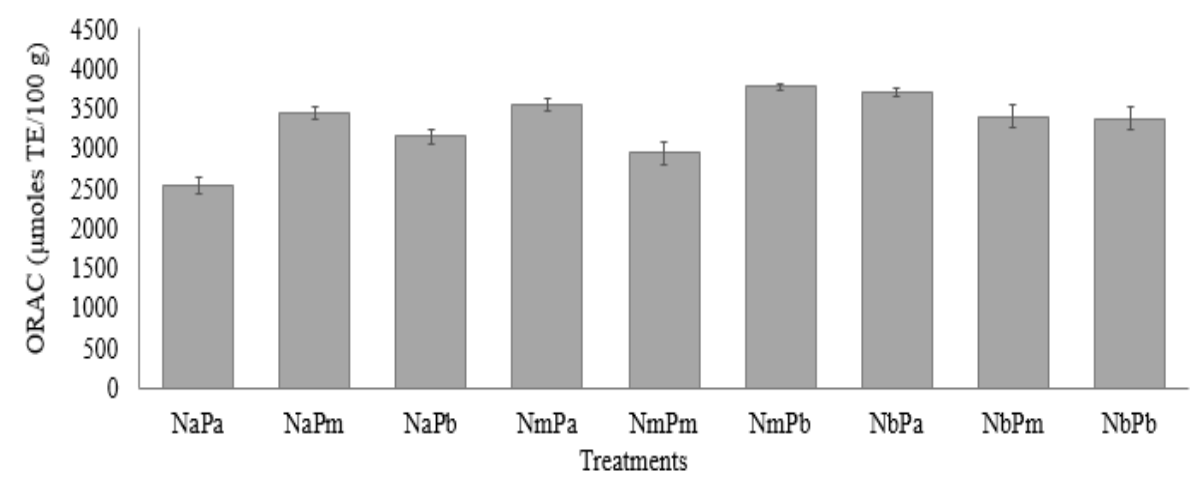

Figure 6. Antioxidant capacity, measured in $\mu$ moles, of the TE/100g sample.

\section{Determination of antioxidant capacity}

The results obtained for the antioxidant capacity by means of the ORAC method are presented in Figure 6, where the greater antioxidant capacity was for the treated $\mathrm{NmPb}$ with a value of 3774.59 $\mu \mathrm{mol} \mathrm{TE} / 100 \mathrm{~g}$ sample and standard deviation of \pm 37.92 . On the other hand, the lowest capacity was $2534.68 \pm 98.9 \mu \mathrm{mol} \mathrm{TE} / 100 \mathrm{~g}$ sample, obtained with $\mathrm{NaPa}$.

\section{DISCUSSION}




\section{THE EFFECT OF DIFFERENT CONCENTRATIONS OF NITROGEN AND PHOSPHOROUS}

\section{ON THE PRODUCTION OF LIPID METABOLITES IN Haematococcus pluvialis UTEX 2505}

Morphological changes were detected in the different stages of growth of $H$. pluvialis UTEX 2505, indicating that the limitation of nutrients generates stress in the cells. In the same manner, the transition of the color (Figure 1.A.) during the growth stages suggests that in the maturation of the cell, changes in the photosynthetic pigments take place, while the accumulation of the antioxidant generates an alteration in photosynthesis that moves from an active state to one of rest. Lv et al. (2016) reported that the content of chlorophyll $a$ decrease as it goes through the vegetative, palmella, aplanospore stage to reach $17.3,6.2$ and $100 \mathrm{mg} / \mathrm{g}$, respectively. Furthermore, chlorophyll $b$ presents a similarly decreasing tendency (16.7 to $0.9 \mathrm{mg} / \mathrm{g}$ ) throughout the cultivation time.

With respect to the morphological change during the vegetative and aplanospore stages, it is apparent that an increase in the synthesis of astaxanthin and total carotenoids can be increased by up to 14.6 and 8.5 times, respectively (Figure 1), as previously suggested (Lv et al., 2016).

In Figure 1.C, the cell in the aplanospore stage (right) presents some irregularities on the surface, in contrast to the vegetative stage (left) where it is smoother or less rough, indicating that the surface of the cell undergoes slight modifications when there is an accumulation of astaxanthin.

Despite the effect of the factors (nitrogen and the phosphorus source) on the surface of the microalga during its last stage of growth, no representative morphological changes were observed between the cells, although authors such as Miranda et al. (2019) suggest that the limitation of nutrients such as nitrogen and phosphorus decrease the rigidity in the cell wall of the microalga, which could be associated with the accumulation of astaxanthin.

The results of the present study in relation to cell growth are comparable to those reported by Nagaraj et al., (2017), where varying stress conditions on $H$. pluvialis, especially macronutrient limitations such as phosphorus and nitrogen, negatively affected the cell growth.

It is possible that this can be explained from the perspective of cellular metabolism because the deficiency of nitrogen reduces the division of the cell, while the limitation of phosphorus hinders the transfer of energy and the formation of membranes, amongst other biological functions (Harker et al., 1996; Nagaraj et al., 2012).

The biomass productivity of $H$. pluvialis UTEX 2505 is comparable to that reported in the literature, of $0.06 \mathrm{~g} / \mathrm{l}$ day (García-Malea et al., 2005) and $0.052 \mathrm{~g} / \mathrm{l}$ day (Olaizola, 2000). Pan-utai et al. (2017) and Li et al. (2017) increased biomass productivity by modifying conditions such as $\mathrm{CO}_{2}$ injection, light intensity, and the design of the photobioreactor to obtain values of $0.35 \mathrm{~g} / \mathrm{l}$ day and $0.66 \mathrm{~g} / 1$.

As is shown in Figure 4, the NbPm treatment generated the maximum carotenoid accumulation of $76.216 \mu \mathrm{g} / \mathrm{ml}$ in comparison to the others. It indicates that low concentrations of nutrients such as nitrates and phosphates favor the synthesis of antioxidants, while it also maintains the cells of $H$. pluvialis UTEX 2505 in vegetative growth for longer time periods alongside the cultivation, thus reaching good cell density. It is important to highlight that one of the main bottlenecks to the scaling of this process to industrial production is the low productivity of biomass and high carotenoid synthesis (Panis \& Carreon, 2016). 


\section{THE EFFECT OF DIFFERENT CONCENTRATIONS OF NITROGEN AND PHOSPHOROUS}

\section{ON THE PRODUCTION OF LIPID METABOLITES IN Haematococcus pluvialis UTEX 2505}

However, Nahidian et al. (2018) note that this behavior could be due to the role that phosphorus plays in the synthesis of chlorophyll through the increased production of ATP and polyphosphate accumulation. On the other hand, Scibilia et al. (2015) underline that the starvation of nitrogen promotes the biosynthesis and accumulation of astaxanthin, as the cells of $H$. pluvialis redirect their metabolism to the accumulation of lipids (monomeric or oligomeric acids) and carotenoids.

Thompson (1996) reports that, when reducing cell growth due to nutrient deficiency, the fatty acids that are still produced are no longer used for the construction of new membranes but are stored in the form of triglycerides to be used as energy when the conditions for growth improve. This is the reason why the lipid content under stress conditions can triple the percentage of lipids compared to a culture under more favorable conditions (Lei et al., 2012). These results are comparable to those obtained in the present study, where the lipid content increased as the concentration of the macronutrients (nitrogen and phosphorus) decreased.

It should be noted that the treatments with the lowest concentration $(0.2 \mathrm{~g} / \mathrm{l})$ of nitrate underwent a gradual decreasing of the lipid content as the phosphorus also decreased. The fatty acids in $H$. pluvialis UTEX 2505 can be contrasted with those reported by Sanchez et al. (2012) and Damiani et al. (2010) for the same microalgae strain, being the linoleic acid (also known as omega 3), which is obtained in greater quantities and stands out for its high commercial value.

From the higher values of the antioxidant capacity of all of the treatments (ORAC), it is possible to affirm that the biomass of $H$. pluvialis UTEX 2505 is an excellent source of natural antioxidants, as they feature superior values to fruits and extracts considered with high-capacity antioxidants, such as the strawberry (540 $\mu \mathrm{mol} \mathrm{TE} / 100 \mathrm{~g}$; see Ahmed et al., 2014), blueberries (46 $\mu \mathrm{mol} \mathrm{TE} / 100$ g; see Prior et al., 2000; and Huang et al., 2002) and cinnamon (1256 $\mu \mathrm{mol} \mathrm{TE} / 100 \mathrm{~g}$; see Su et al., 2007). The $\mathrm{N}_{\mathrm{m}} \mathrm{P}_{\mathrm{b}}$ treatment showed greater antioxidant capacity (3774. $59 \mu \mathrm{mol} \mathrm{TE} / 100 \mathrm{~g}$ ) against the other treatments, and therefore it has a high power of absorption of free radicals and can serve as a nutritional supplement to counteract the oxidative stress.

\section{CONCLUSIONS}

According to the results obtained, the samples with medium concentrations of nitrogen and low concentrations of phosphorous had a positive effect on the accumulation of lipid metabolites in $H$. pluvialis UTEX 2505. Also, with this concentration it was achieved a maximum peak of cell growth of $0.7 \mathrm{~g} / \mathrm{L}$ during the 12 day of culture and $55 \mathrm{ug} / \mathrm{ml}$ of astaxanthin. There were morphological changes, but they were not significative.

Likewise, this treatment showed a high antioxidant capacity of $3774.59 \mu \mathrm{mol}$ TE / $100 \mathrm{~g}$ compared to the other treatments, obtaining the property of counteracting the oxidative stress. That is why biomass obtained is postulated as a potential product for the nutraceutical industry due to the accumulation of astaxanthin, its significative lipid content and superior antioxidant value over classical compounds such as vitamins $\mathrm{E}$ and $\mathrm{C}$.

\section{ACKNOWLEDGEMENTS}


THE EFFECT OF DIFFERENT CONCENTRATIONS OF NITROGEN AND PHOSPHOROUS

ON THE PRODUCTION OF LIPID METABOLITES IN Haematococcus pluvialis UTEX 2505

334 The authors would like to convey their thanks to EAFIT University and the Argos Center for

335 Innovation for financing this work.

336 COMPETING INTERESTS

337 The authors declare have no conflicts of interest to disclose.

AVAILABILITY OF DATA AND MATERIALS

339 The data that support the findings of this study are available from Argos S.A.S. and EAFIT

340 University, but restrictions apply to the availability of these data, which were used under license

341 for the current study, and so are not publicly available. Data are however available from the authors

342 upon reasonable request and with permission of Argos S.A.S. and EAFIT University.

343 ETHICS APPROVAL AND CONSENT TO PARTICIPATE

344 Not applicable

345 CONSENT FOR PUBLICATION

346 Not applicable

347 FUNDING

348 This work was supported by EAFIT University and Argos S.A.S.

349 AUTHORS' CONTRIBUTIONS

350 Brenda Hoyos, Alejandra Miranda, Diana Meneses, Gabriel Vargas and Alex Sáez contributed to

351 the design and implementation of the research, to the analysis of the results and to the writing of the

352 manuscript.

353 AUTHORS' INFORMATION

354 Brenda Hoyos

355 bhoyosg@eafit.edu.co

$356+573005252383$

357 Alejandra Miranda

358 ammirandap@eafit.edu.co

$359+573002182421$

360 Alex Saez

361 asaez@eafit.edu.co

$362+573218305427$

363 
THE EFFECT OF DIFFERENT CONCENTRATIONS OF NITROGEN AND PHOSPHOROUS

ON THE PRODUCTION OF LIPID METABOLITES IN Haematococcus pluvialis UTEX 2505

SUMMARY OF ABBREVIATIONS

\begin{tabular}{|c|c|}
\hline \multicolumn{2}{|c|}{ Abbreviations } \\
\hline University of Texas at Austin & UTEX \\
\hline Scanning electron microscope & SEM \\
\hline Dimethilsulfoxide & DMSO \\
\hline Oxygen radical absorbance capacity & ORAC \\
\hline Analysis of variance & ANOVA \\
\hline Cell growth & $\mu$ \\
\hline Maximum biomass & Xmax \\
\hline
\end{tabular}

REFERENCES

Ahmed, F., Fanning, K., Netzel, M., Turner, W., Li, Y., Schenk, P. 2014. Profiling of carotenoids and antioxidant capacity of microalgae from subtropical coastal and brackish waters. Food Chemistry. 165, 300-306.

Camacho, J., González, G., Klotz, B. 2013. Producción de Astaxantina en Haematococcus Haematococcus pluvialis (Chlorophyceae). Plant Journal. 81(1), 95-107. 357.

Dai, Y. M., Chen, K. T., Chen, C. 2014. Study of the microwave lipid extraction from microalgae for biodiesel production. Chemical Engineering Journal. 250, 267-273. 
Gao, Z., Meng, C., Zhang, X., Xu, D., Miao, X., Wang, Y., Ye, N. 2012. Induction of salicylic acid (SA) on transcriptional expression of eight carotenoid genes and astaxanthin accumulation in Haematococcus pluvialis. Enzyme and Microbial Technology. 51(4), 225-230.

García-Malea, M. C., Brindley, C., Del Río, E., Acién, F. G., Fernández, J. M., Molina, E. 2005. Modelling of growth and accumulation of carotenoids in Haematococcus pluvialis as a function of irradiance and nutrients supply. Biochemical Engineering Journal. 26(2-3), 107-114.

Giannelli, L., Yamada, H., Katsuda, T., Yamaji, H. 2015. Effects of temperature on the astaxanthin productivity and light harvesting characteristics of the green alga Haematococcus pluvialis. Journal of Bioscience and Bioengineering. 119(3), 345-350.

Harker, M., Tsavalos, A. J., Young, A. J. 1996. Factors responsible for astaxanthin formation in the chlorophyte Haematococcus pluvialis. Bioresource Technology. 55(3), 207-214.

Huang, L., Kirschke, C. P., Gitschier, J. 2002. Functional characterization of a novel mammalian zinc transporter, ZnT6. Journal of Biological Chemistry. 227(29), 26389 -26395.

Lei, A., Chen, H., Shen, G., Hu, Z., Chen, L., Wang, J. 2012. Expression of fatty acid synthesis genes and fatty acid accumulation in haematococcus pluvialis under different stressors. Biotechnology for Biofuels. 5(1), 5-18.

Li, K., Cheng, J., Lu, H., Yang, W., Zhou, J., Cen, K. 2017. Transcriptome-based analysis on carbon metabolism of Haematococcus pluvialis mutant under $15 \% \mathrm{CO}_{2}$. Bioresource Technology. 233, 313-321.

Luque de Castro, M. D., Priego-Capote, F. 2010. Soxhlet extraction: Past and present panacea. Journal of Chromatography A. 1217(16), 2383-2389.

Lv, H., Xia, F., Liu, M., Cui, X., Wahid, F., Jia, S. 2016. Metabolomic pro fi ling of the astaxanthin accumulation process induced by high light in Haematococcus pluvialis. Algal. 20, 35-43.

Markou, G., Nerantzis, E. 2013. Microalgae for high-value compounds and biofuels production: A review with focus on cultivation under stress conditions. Biotechnology Advances. 31(8), 1532-1542. 
THE EFFECT OF DIFFERENT CONCENTRATIONS OF NITROGEN AND PHOSPHOROUS

ON THE PRODUCTION OF LIPID METABOLITES IN Haematococcus pluvialis UTEX 2505

423

424

425

426

427

428

429

430

431

432

433

434

435

436

437

438

439

440

441

442

443

444

445

446

447

448

449

450

451

452

453

454

455

456
Miranda, A., E. Ossa., G. Vargas., A. Sáez, 2019. Efecto de las bajas concentraciones de nitratos y fosfatos sobre la acumulación de astaxantina en Haematococcus pluvialis UTEX 2505. Información tecnológica. 30(1), en prensa.

Nagaraj, S., Arulmurugan, P., Rajaram, M. G., Sundararaj, R., Rengasamy, R. 2012. Enhanced production of astaxanthin at different physico-chemical parameters in the green alga

Haematococcus pluvialis Flotow. Phykos. 42(1), 59-71.

Nahidian, B., Ghanati, F., Shahbazi, M., Soltani, N. 2018. Effect of nutrients on the growth and physiological features of newly isolated Haematococcus pluvialis TMU. Bioresource Technology. 255, 229-237.

Niño Castillo, C. M., Rodríguez Rivera, F. C., Díaz, L. E., Lancheros Díaz, A. G. 2017.

Evaluación de las condiciones de crecimiento celular para la producción de astaxantina a patir de la microalga Haematococcus pluvialis. Nova. 15(28), 19-31.

Olaizola, M. 2000. Commercial production of astaxanthin from Haematococcus pluvialis using 25,000-liter outdoor photobioreactors. Journal of Applied Phycology. 12, 499-506.

Orosa, M., Franqueira, D., Cid, A., Abalde, J. 2005. Analysis and enhancement of astaxanthin accumulation in Haematococcus pluvialis. Bioresource Technology. 96(3), 373-378.

Pan-utai, W., Parakulsuksatid, P., Phomkaivon, N. 2017. Effect of inducing agents on growth and astaxanthin production in Haematococcus pluvialis: Organic and inorganic. Biocatalysis and Agricultural Biotechnology. 12, 152-158.

Panis, G., Carreon, J. R. 2016. Commercial astaxanthin production derived by green alga Haematococcus pluvialis : A microalgae process model and a techno-economic assessment all through production line. Algal. 18, 175-190.

Prior, R. L., Cao, G. 2000. Antioxidant phytochemicals in fruits and vegetables: Diet and health implications. HortScience. 35(4), $588-592$.

Rautenbach, F., Faber, M., Laurie, S., Laurie, R. 2010. Antioxidant capacity and antioxidant content in roots of 4 sweetpotato varieties. Journal of Food Science. 75(5), $400-405$. 
THE EFFECT OF DIFFERENT CONCENTRATIONS OF NITROGEN AND PHOSPHOROUS

ON THE PRODUCTION OF LIPID METABOLITES IN Haematococcus pluvialis UTEX 2505

Saha, S. K., McHugh, E., Hayes, J., Moane, S., Walsh, D., Murray, P. 2013. Effect of various stress-regulatory factors on biomass and lipid production in microalga Haematococcus pluvialis. Bioresource Technology, 128, 118-124.

Sánchez, A. P., Meireles, M., Ferreira, A., Saito, E., Cabral, F. 2012. Extraction of $\omega-3$ fatty acids and astaxanthin from Brazilian redspotted shrimp waste using supercritical $\mathrm{CO}_{2}+$ ethanol mixtures. Journal of Supercritical Fluids. 61, 71-77.

Satoh, T. 2016. Astaxanthin Health Benefits and Toxicity En: T. Satoh (ed). Nutraceuticals. Elsevier, pp. 531-539.

Scibilia, L., Girolomoni, L., Berteotti, S., Alboresi, A., Ballottari, M. 2015. Photosynthetic response to nitrogen starvation and high light in Haematococcus pluvialis. Algal. 12, 170-181.

Shang, M., Ding, W., Zhao, Y., Xu, J. W., Zhao, P., Li, T., Yu, X. 2016. Enhanced astaxanthin production from Haematococcus pluvialis using butylated hydroxyanisole. Journal of Biotechnology. 236, 199-207.

Thompson, G. 1996. Lipids and membrane function in green algae. Biochimica et Biophysica Acta (BBA) - Lipids and Lipid Metabolism. 1302, 17 - 45.

Wang, J., Guleria, S., Koffas, M. A., Yan, Y. 2016. Microbial production of value-added nutraceuticals. Current Opinion in Biotechnology. 37, 97-104.

Zapata, S., Piedrahita, A. M., Rojano, B. 2014. Capacidad atrapadora de radicales oxígenos (ORAC) y fenoles totales de frutas y hortalizas de Colombia. Perspectivas En Nutrición Humana. $16(1), 25-36$.

Zhang, B. Y., Geng, Y. H., Li, Z. K., Hu, H. J., Li, Y. G. 2009. Production of astaxanthin from Haematococcus in open pond by two-stage growth one-step process. Aquaculture. 295(3-4), 275-281. 
THE EFFECT OF DIFFERENT CONCENTRATIONS OF NITROGEN AND PHOSPHOROUS

ON THE PRODUCTION OF LIPID METABOLITES IN Haematococcus pluvialis UTEX 2505

489 Zhekisheva, M., Boussiba, S., Khozin-Goldberg, I., Zarka, A., Cohen, Z. 2002. Accumulation of 490 oleic acid in Haematococcus pluvialis (Chlorophyceae) under nitrogen starvation or high light is 491 correlated with that of astaxanthin esters. Journal of Phycology. 38(2), 325-331. 


\section{Figures}

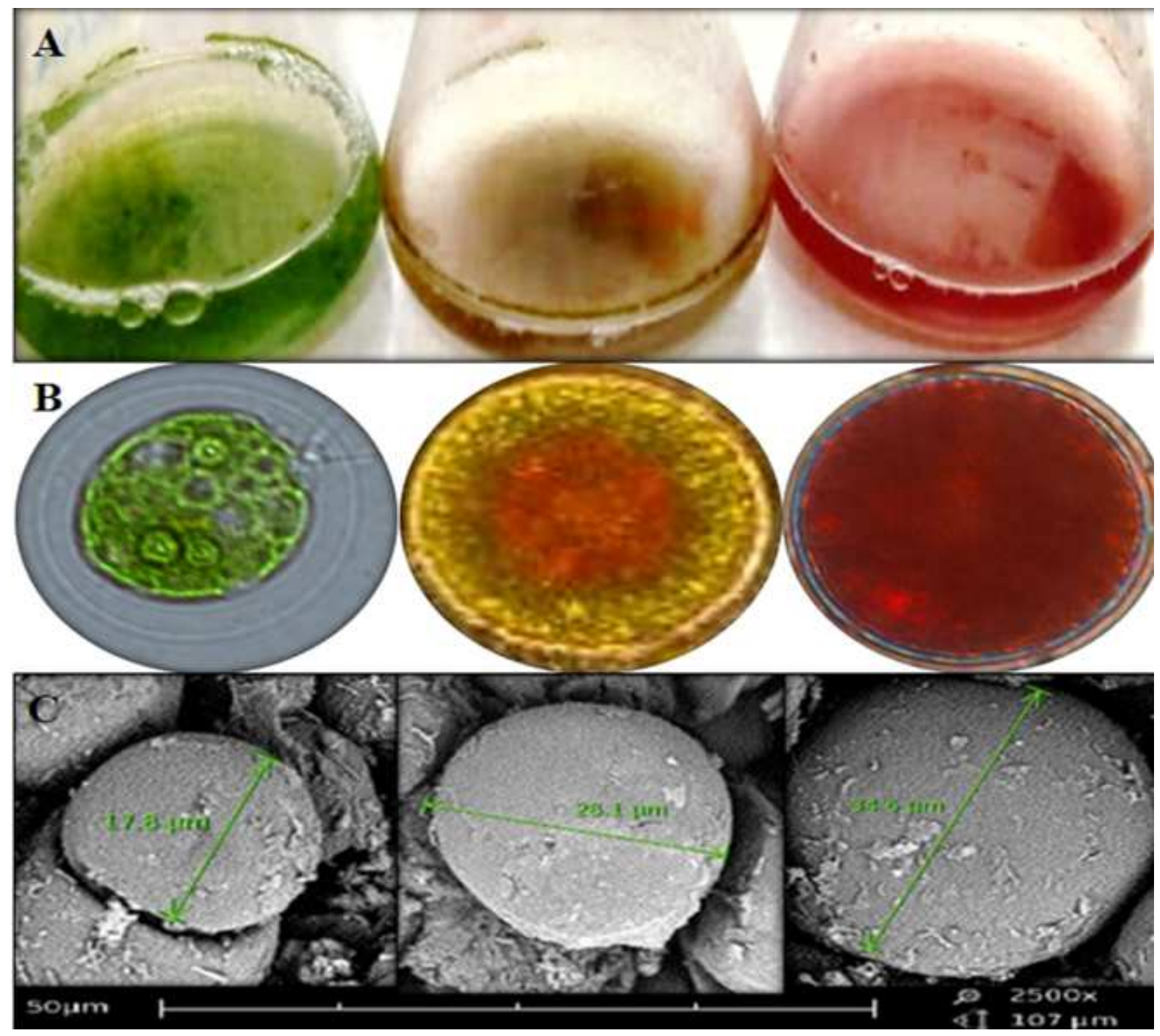

\section{Figure 1}

Micrographs of H. pluvialis UTEX 2505 in its main three growth stages: A. Microalga in suspension B; state of the cells taken in the optical microscope C; cell surface morphology taken with SEM. 

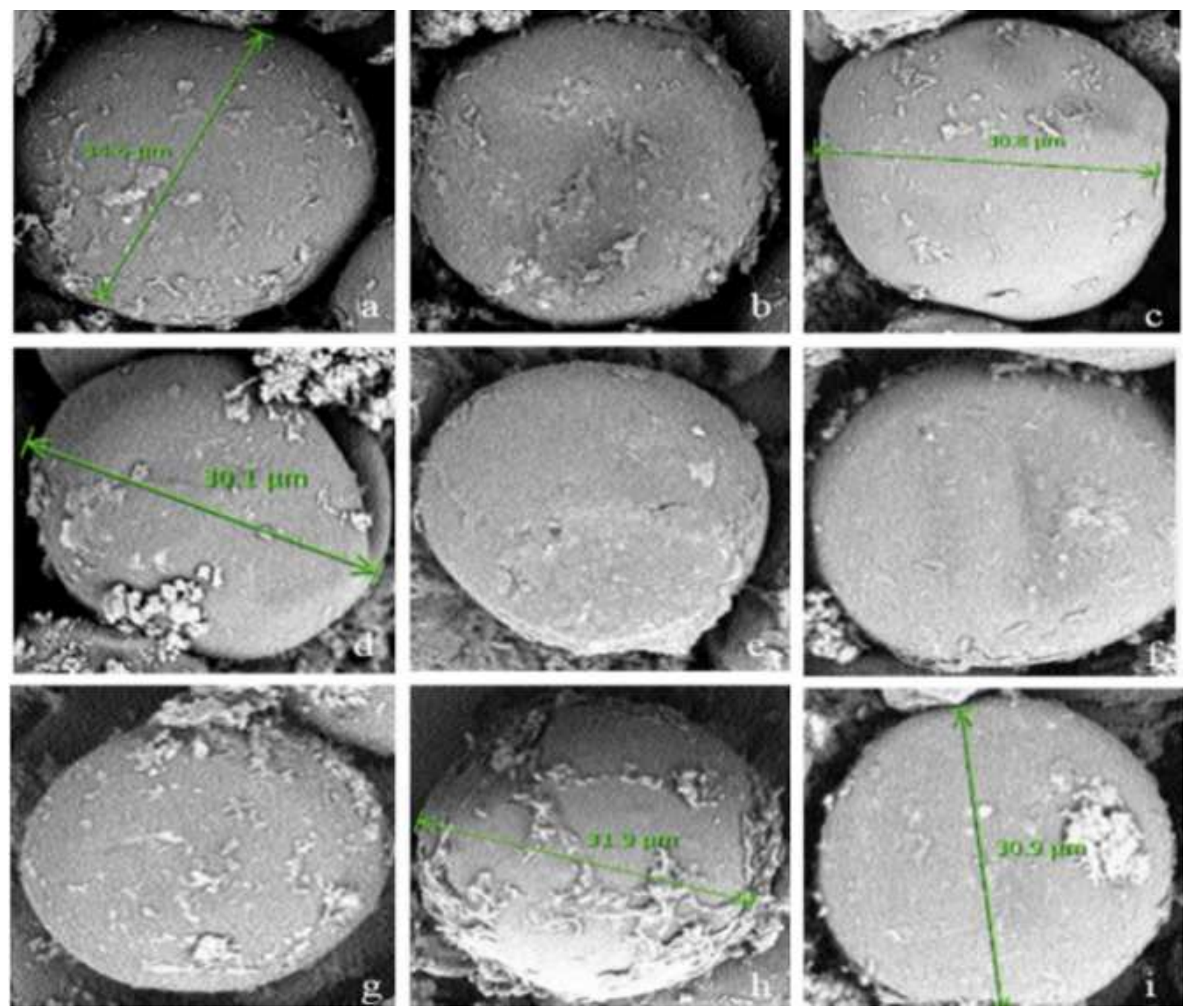

Figure 2

Morphology of the cell surface in the last stage of cell growth (aplanospora), taken with SEM. 

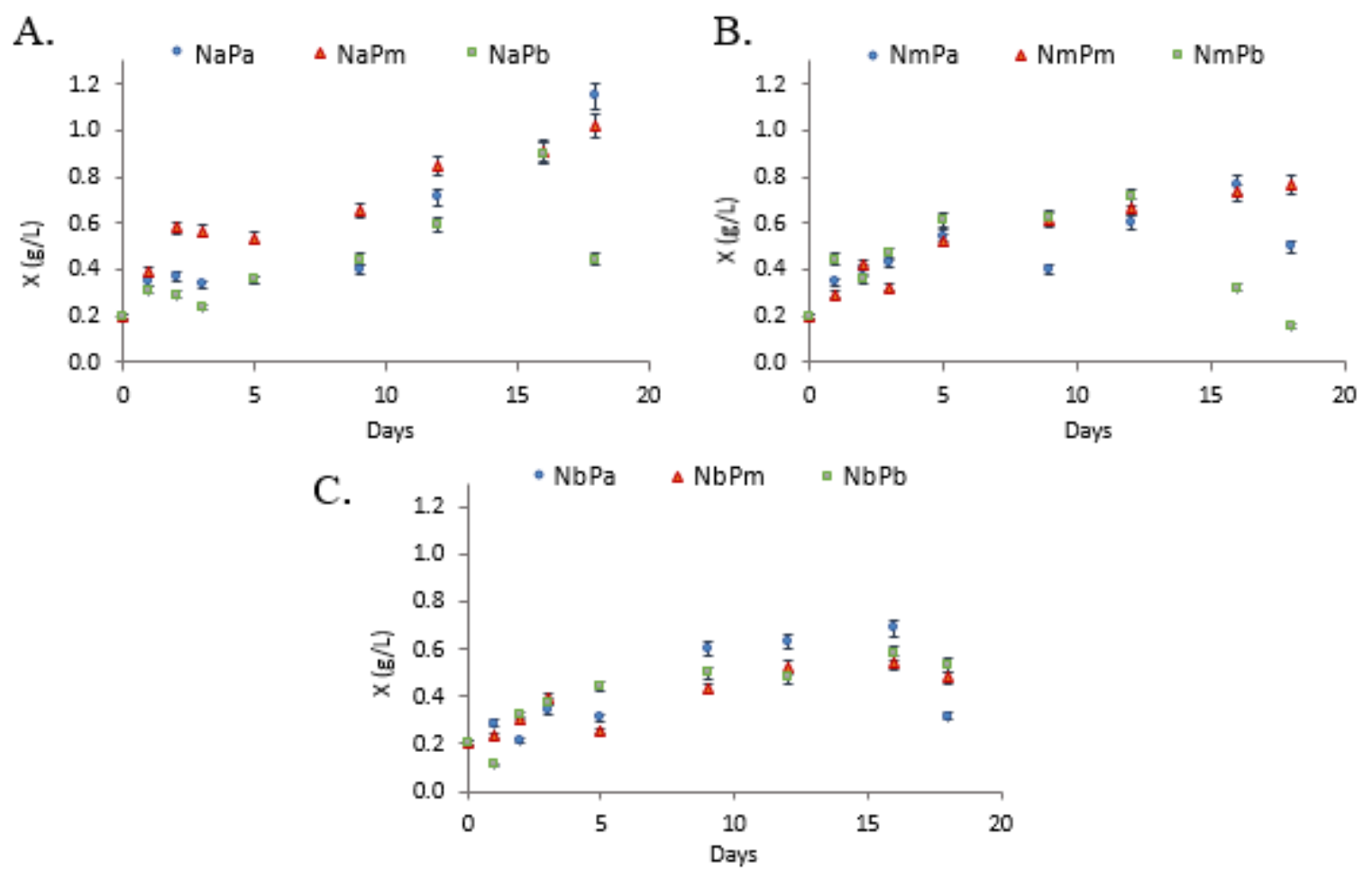

\section{Figure 3}

Growth kinetics for the treatments, where $\mathrm{X}$ is the biomass in $\mathrm{g} / \mathrm{l}$ in a time range of 18 days.

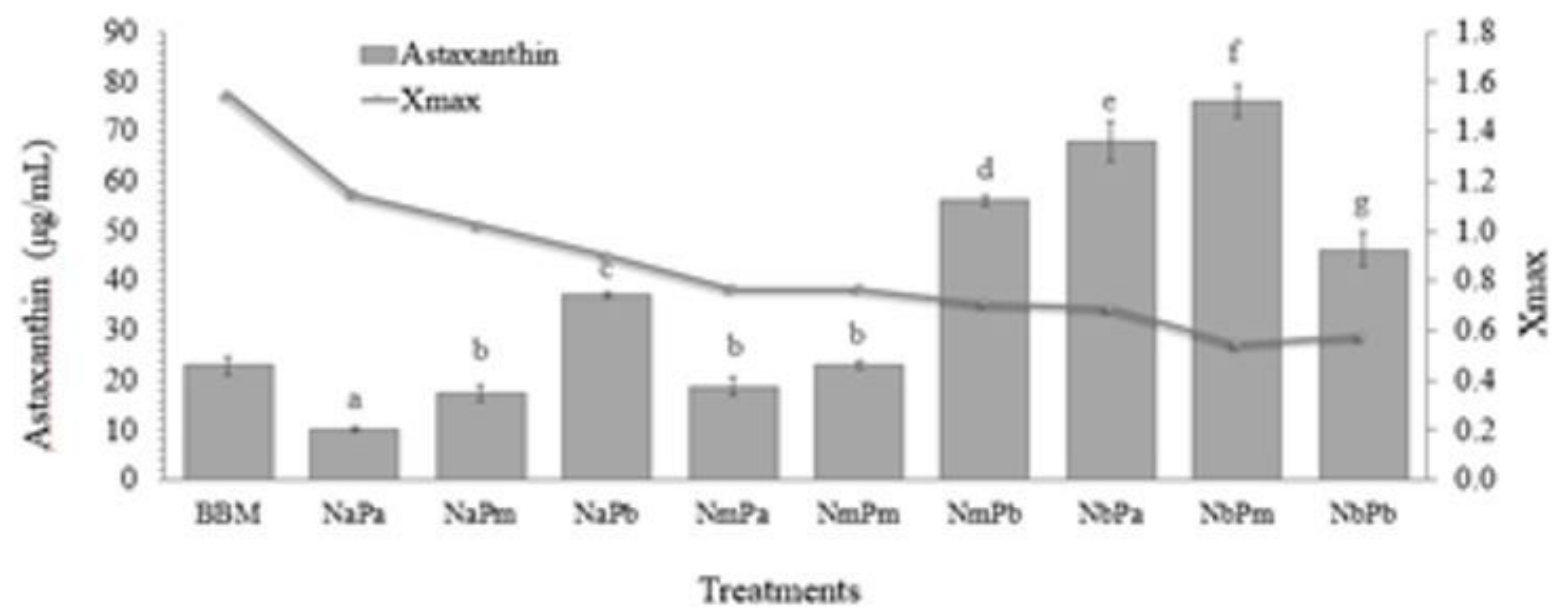

Figure 4

Relationship between the concentration of astaxanthin in $\mu \mathrm{g} / \mathrm{ml}$ of $\mathrm{H}$. pluvialis UTEX 2505 and the maximum biomass for all the treatments. Equal letters correspond to statistically homogeneous groups according to Fisher's minimum significant difference test (LSD), with a confidence level of $95 \%$. 
A

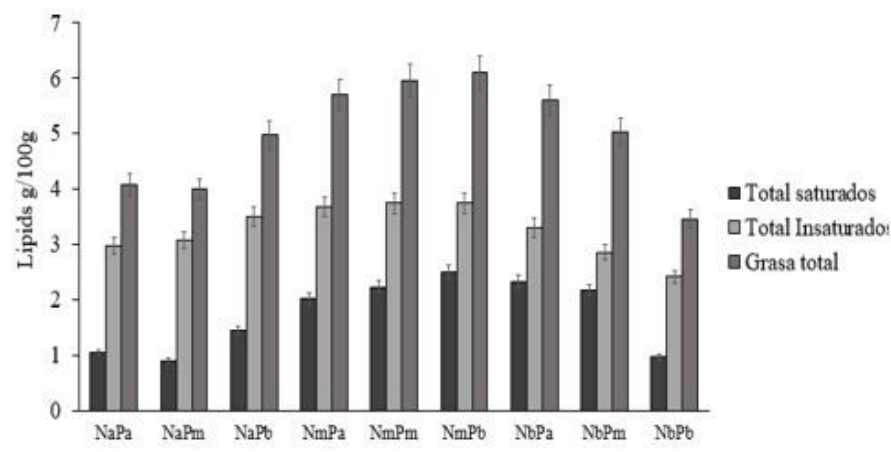

B

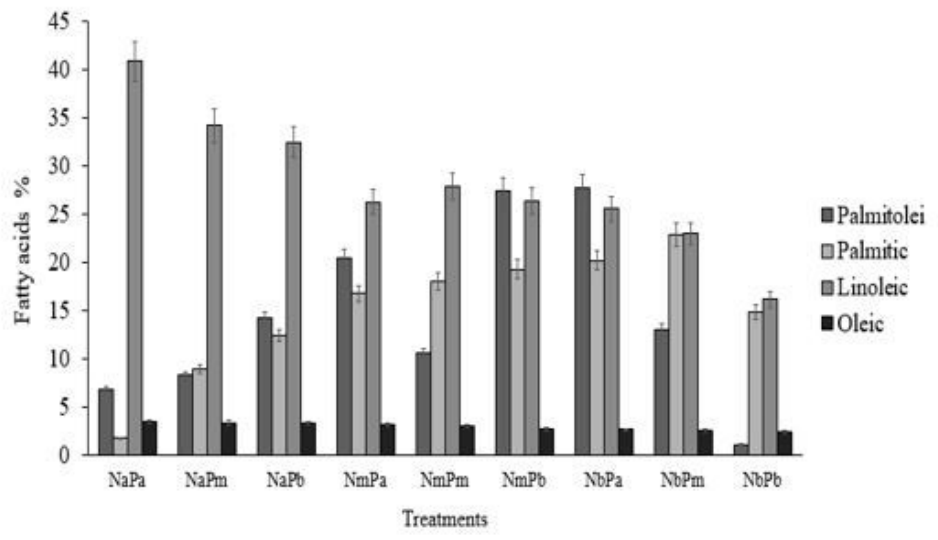

Figure 5

A. Lipid concentration ( $\mathrm{g} / 100 \mathrm{~g}$ of biomass) of H. pluvialis UTEX 2505 for the different treatments. B. Percentage of the main fatty acids synthetized with each treatment.

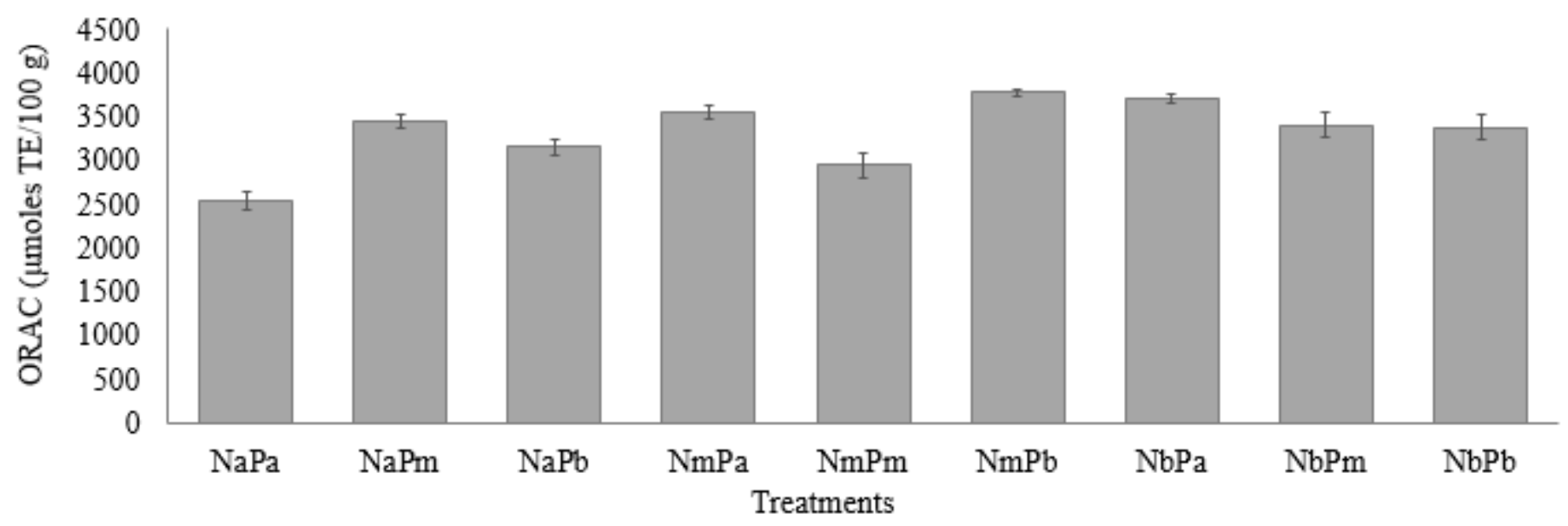

Figure 6

Antioxidant capacity, measured in $\mu$ moles, of the TE/100g sample.

\section{Supplementary Files}

This is a list of supplementary files associated with this preprint. Click to download.

- DiagramaprocesoH.pluvialisPage1.png 